\section{Rosario, Santa Fe y la polémica Severo Gómez - Lisandro de la Torre}

Santiago Javier Sánchez

Santiago Javier Sánchez,

Université de Montréal, 5795 Avenue Christophe

Colomb, H2S 2E8 Montréal, Québec, Canadá

e-mail: santiago.javier.sanchez@umontreal.ca

\section{Resumen}

Durante el año 1910, Lisandro de la Torre, líder del partido político «Liga del Sur», y Severo Gómez, director del periódico El Constitucional, intercambiaron una serie de cartas. En ellas, reflexionaron sobre el rol de las ciudades de Rosario y Santa Fe. De la Torre defendía Rosario, una ciudad joven forjada por inmigrantes europeos, que simbolizaba, para él, la nueva Argentina y el progreso. Gómez, por su parte, defendía Santa $\mathrm{Fe}$, una ciudad tradicional, "criolla", con una larga y gloriosa historia.

\section{Summary}

During the year 1910, Lisandro de la Torre, leader of the political party «Liga del Sur» and Severo Gómez, the director of the newspaper El Constitucional, interchanged a series of letters. In these letters, they reflected about the role of Rosario and Santa Fe cities. De la Torre defended Rosario, a young town made by European immigrants, which symbolized, for him, the new Argentina and progress. Gómez, in the other hand, defended Santa Fe, a traditional and 'criolla' town with a long and glorious history. 